\title{
Risk-based Capital Requirements for Mortgage Loans
}

\author{
Paul S. Calem \\ Division of Research and Statistics \\ Board of Governors of the Federal Reserve System \\ and \\ Michael LaCour-Little \\ Wells Fargo Home Mortgage, Inc. \\ $\&$ \\ Washington University in St. Louis
}

November 2001

\begin{abstract}
We develop estimates of risk-based capital requirements for single-family mortgage loans held in portfolio by financial intermediaries. Our method relies on simulation of default and loss probability distributions via simulation of changes in economic variables with conditional default probabilities calibrated to recent actual mortgage loan performance data from the 1990s. Based on simulations with varying input parameters, we find that appropriate capital charges for credit risk vary substantially with loan or borrower characteristics and are generally below the current regulatory standard. These factors may help explain the high degree of securitization, or regulatory capital arbitrage, observed in this asset category.
\end{abstract}

We thank Jim Berkovec, Michael Gordy, John Gruenstein, Arden Hall, and David Jones as well as Bob Edelstein, John Quigley, Nancy Wallace and seminar participants at the University of California at Berkeley; Phil Dybvig and seminar participants at Washington University in St. Louis; and Mark Flannery, David Ling and seminar participants at the University of Florida for helpful comments. The views presented are solely those of the authors and do not necessarily represent those of the Federal Reserve Board or its staff. 


\section{Risk-based Capital Requirements for Mortgage Loans}

\section{Introduction}

Banks play a central role in the economy through their liquidity- and credit-creation functions. But their asset-liability structure makes them fragile and any loss of confidence can produce bank runs. Bank assets are risky loans while their liabilities are not contingent claims but relatively short-term deposits. In the United States, deposit insurance reduces uncertainty regarding the security of bank liabilities; in addition, ongoing supervision and regulatory capital requirements mitigate the risk of insolvency. The public costs of widespread financial distress in the banking sector can be substantial, as the savings and loan debacle of the late 1980s and early 1990s demonstrated.

Given that capital regulation is an appropriate market intervention recognizing the special status of banks in the economy, what standards should regulatory agencies require of depository institutions under their supervision? This question is central to the Basel Committee for Banking Supervision, which is in the process of revising the capital standards to align regulatory requirements with actual risk. Similarly, capital levels are critical to the Office of Housing Enterprise Oversight, which supervises the huge government-sponsored enterprises (Fannie Mae and Freddie Mac, hereafter called the GSEs) operating in the secondary mortgage market. In addition, effective internal risk management also requires appropriate capital allocations.

In this paper, we use a value-at-risk approach to develop capital standards for residential mortgage credit risk. We restrict our attention to 30-year single-family fixed-rate mortgages (FRMS), the most commonly used instrument to finance owner-occupied housing in the United

States ${ }^{1}$, further restricting focus to mortgages of conforming size ${ }^{2}$. This asset type seems the natural starting point for analysis of capital requirements for mortgage assets; moreover, our method is sufficiently general to be applied to other contract structures in future extensions. While adjustable rate mortgages (ARMS) are widely held in institutional portfolios, modeling default and prepayment on these instruments is significantly more complex compared to FRMS.

\footnotetext{
${ }^{1}$ The mortgage market is huge, exceeding the size of the government bond market. As of 1999, a total of $\$ 5.9$ trillion in mortgage debt was outstanding, with single-family mortgage debt of $\$ 4.4$ trillion representing the largest share. Commercial banks and savings institutions directly hold about 34 percent of total mortgage debt. An additional $47 \%$ has been securitized in agency and non-agency mortgage-backed securities. Other financial institutions, such as insurance companies, and individuals hold the balance.

${ }^{2}$ Mortgages may be divided into conforming, i.e. eligible for purchase by the government-sponsored enterprises (Fannie Mae and Freddie Mac) and nonconforming. A primary criterion is loan size-larger loans (jumbos) are nonconforming. The current cut-off point is $\$ 275,000$ for single-family properties.

${ }^{3}$ See, for example, Ambrose and LaCour-Little [2001] for discussion of the complexities associated with modeling adjustable rate mortgage performance.
} 
Also, many ARMS today have initial fixed rate terms of five to seven years, horizons that cover most of the credit risk period.

We also restrict our attention to capital for credit risk. Mortgage portfolios are also subject to interest rate risk, including prepayment risk, exposure to which is typically managed through a variety of hedging strategies. In contrast, credit risk (while manageable through prudent underwriting, mortgage insurance, and securitization), cannot be directly hedged. Accordingly, we do not consider interest rate risk here, except to the extent we jointly model prepayment and default. This approach is consistent with current regulatory and industry practice.

We find that the bank capital required to match the insolvency probability of a BBB-rated commercial bond (for instance, an eight-year cumulative insolvency probability of 2.5 percent) is generally lower than current regulatory standards. Moreover, the appropriate capital level depends importantly on underwriting variables (the loan-to-value ratio and the credit rating of the borrower) and on the degree of portfolio geographic diversification. The latter effect is particularly important in light of the regional concentration of some large institutions.

For instance, we calculate that newly originated loans with 80 percent loan-to-value ratios and a prime borrower credit score of 700 require very little capital to cover credit risk: no more than 0.51 percent in a well-diversified portfolio and 0.90 percent in a regionally concentrated portfolio, assuming a BBB solvency standard and an eight year horizon. Diversification has a similar impact for loans with higher expected loss rates. For example, a 90 percent loan-to-value ratio combined with a sub-prime level credit score of 660 implies a capital charge of at most 1.83 percent when the portfolio is geographically diversified and 3.19 percent in a regionally concentrated portfolio. Current capital rules under the 1988 Basel Accords assign a 50 percent risk weight to most residential mortgage loans, thus requiring a 2 percent tier one (equity) capital ratio. Our findings suggest substantial differences in credit risk across mortgage categories and between residential mortgages and other types of assets. Accordingly, current rules may encourage regulatory capital arbitrage, including increased rates of securitization of mortgage assets.

To assess appropriate capital levels we need to understand the shape of loss distributions for various sub-portfolios of mortgage assets. Economic capital may then be allocated in proportion to the distance between a specified, far-tail loss rate of the distribution and the expected loss rate (a measure termed "value-at-risk."). Models applying simulation techniques to generate loss probability distributions in recent years have become standard tools to evaluate 
economic capital for corporate-debt credit risk. ${ }^{⿴}$ Economic capital for residential mortgages has received less attention. ${ }^{\text {G }}$ employ a semi-parametric procedure for modeling credit loss distributions. The procedure combines empirical survival curves, simulated scenarios for house prices, interest rates, and employment drawn from history, and calibration of the costs associated with foreclosure to yield probability distributions over losses due to default. This approach has a number of advantages. First, it takes full advantage of available historical data on mortgage loan performance. Second, it employs hazard rate methods that are currently the state-of-the-art in mortgage termination risk research. ${ }^{6}$ Third, it employs a non-parametric re-sampling method (as in Carey [1998]) to derive probability distributions over future paths of employment, house prices, and interest rates environments, whereby risk-factor scenarios are generated by MonteCarlo re-sampling from historical data.

The Office of Federal Housing Enterprise Oversight (OFHEO) recently proposed a riskbased capital rule for Fannie Mae and Freddie Mac based on a stress test. Such an approach involves arbitrary extrapolation from historical data and, for a regionally diversified portfolio, may imply a higher capital requirement than would be obtained under a loss-distribution approach (for instance, under the OFHEO stress test, the house price depreciation that occurred in a few states during the early to mid-1980s is assumed to occur nationwide.) Our procedure retains the overall flavor of a stress test but employs a more probabilistic approach to generating stress scenarios.

To estimate the empirical survival curves, we rely on a large and geographically diverse data set from a major financial services firm. Data includes credit ratings for the borrower at the time of loan origination. Inclusion of this important variable helps ensure unbiased estimation of the coefficients of other risk factors, such as current loan-to-value ratio and changes in local unemployment rates. We should also acknowledge data limitations: it only includes loans

\footnotetext{
${ }^{4}$ See Crouhy, Galai, and Mark [2000] and Gordy [2000a] for description and comparative analysis of these models.

${ }^{5}$ LoanPerformance, a company based in San Francisco, has developed a proprietary credit risk model that employs simulation methods to generate probability distributions over credit losses and prepayments for residential mortgage portfolios. In the academic literature, a study close to ours in spirit is Quigley and Van Order (1991), who analyze economic capital using estimates of mean and variance of loss rates by region and covariance across regions.

${ }^{6}$ The academic literature on mortgage termination risk is large, so we mention only a few relevant papers here. Among empirical papers, Von Furstenberg (1969) did early work using FHA loan data. Campbell and Dietrich (1983) extended the analysis to conventional mortgages. Cunningham and Capone (1990) compared the termination probabilities for FRM versus ARM, including prepayment risk. Quercia and Stegman (1992) provide a review of the literature on default. In recent years, survival analysis (especially proportional hazard estimation) with prepayments and default treated as competing risks has become the preferred empirical approach to investigating mortgage credit (see Deng, Quigley, and Van Order [2000] for the most recent approach to competing risk methodology).
} 
originated during 1993-1997, time period when house prices in most (though not all) markets were stable or increasing.

The plan for the balance of the paper is as follows. In the next section, we briefly discuss recent developments in bank capital regulation. The third section describes the data and the empirical hazard models used to calibrate the simulation procedure. In the fourth section we describe the simulation procedure and in the fifth section we report our results. The final section summarizes conclusions and identifies extensions.

\section{Policy Background}

The topic of capital is important in several sub-disciplines of financial economics. In corporate finance, the question of optimal capital structure of the firm has been of interest since the seminal paper by Modigliani and Miller (1958) showing that, in a perfect full-information and frictionless market, capital structure is irrelevant to firm value. Real world departures are attributed to the costs of financial duress, the existence of taxes, asymmetric information, transaction costs, and other factors (Berger et al [1995]). Financial institutions, especially banks, differ from other types of firms inasmuch as most of their debt is held by depositors who are also purchasers of the bank's financial intermediary and payment services. Moreover, banks benefit from the safety net provided by deposit insurance. ${ }^{0}$ As a result, banks have a very strong preference for debt over equity. Recently, Diamond and Rajan (2000) have developed a theory of bank capital, in which tradeoffs among liquidity creation and the costs of financial distress imply an optimal level of capital. Santos (2001) provides a comprehensive review of the role of regulatory capital in banking theory.

The events of the 1980s, including high bank failure rates and the thrift industry debacle, prompted a renewed interest in capital for financial firms, particularly those benefiting from

public sector guarantees. ${ }^{\text {B }}$ The 1988 Basel Accord established a 4 percent standard for tier one (equity) capital in relation to "risk-weighted" assets along with a set of four risk "buckets" corresponding to tier one capital requirements of 0 percent, 0.8 percent, 2.0 percent, and 4.0

\footnotetext{
${ }^{7}$ Berger et al. [1995] depict the long run decline in the level of U.S. bank equity capital levels over time, as various governmental initiatives strengthened the safety net

${ }^{8}$ Regulatory minimum capital requirements for depository institutions serve two major purposes. First, it serves to curtail the risk shifting benefits of deposit insurance and associated moral hazard. Second, it limits taxpayer exposure to banking system losses, particularly to losses not covered by the government safety net (such as fraud and mismanagement.) In addition, a capital standard serves an informational purpose, because a bank's ability to maintain compliance with the standard may signal information about the quality of its assets and management. It is also a legal tool facilitating supervisory intervention at financially weak institutions. The goal of limiting the banking system's exposure to systemic risk is often
} 
percent (Greenspan [1998]). Corporate loans, for example, receive a risk weighting of 100\% (a minimum of $4 \%$ equity capital required) while treasury securities are assigned a 0 risk weighting. Residential mortgage loans generally receive a risk weighting of $50 \%$ (a minimum of $2 \%$ equity capital is required). In addition, the regulations adopted in 1988 set standards for total capital (a broader definition that incorporates loss reserves and some subordinated debt in addition to equity) in relation to risk-weighted assets and for tier-one capital in relation to total assets. Separate assessments are made for off-balance sheet risk exposure and additional charges for interest rate risk may be assessed on a case-by-case basis. Technically, the standards adopted internationally under the Accord apply only to international banks. In the U.S., however, these standards have been extended by statute to all federally insured commercial banks, savings banks, and savings and loan institutions and to the bank or savings and loan holding company level as well.

While, in principle, regulatory capital standards are merely minimum requirements subject to upward revision by regulators based on individual circumstances, in practice, supervisory discretion tends to be limited to unusual circumstances such as a very high concentration of loans within a particular industry category or a substantial duration gap. For instance, loans to A-rated corporate borrowers receive the same capital charge as loans to B-rated corporate borrowers. In the case of mortgages, the 50 percent risk weight is applied to any performing loan that has been "prudently underwritten." In practice, the 50-percent weight has been applied to loans with loan-to-value ratios above 90 percent if they have private mortgage insurance and those with loan-to-value ratios up to 90 percent even without insurance 9

This "one size fits all" approach has been widely criticized as leading to misallocations of capital within and across financial institutions. The current regulatory approach also appears to promote the growing use of securitization and other financial innovations that often enable institutions to reduce regulatory capital requirements with little or no corresponding reduction in overall economic risk (Jones [2000]). This process has come to be called "regulatory capital arbitrage" and has received little academic attention due, in part, to the difficulty of measuring risk transfer under complex asset-backed security structures. Moreover, the proliferation of regulatory capital arbitrage has made it difficult for supervisors to assess an institution's true capital adequacy.

attributed to capital regulation, although the theoretical literature on the relation between capital and bank risk-taking sheds some doubt on the practicality of this goal (for example, Calem and Rob [1999].)

${ }^{9}$ In early 2001, the federal bank regulatory agencies issued a supervisory letter directing supervisory authorities to pay particular attention to sub-prime lending programs and assess additional capital to such loans as appropriate. 
Recognizing these problems, the Basel Committee recently released a proposal for revisions to the risk-based capital guidelines intended to more closely align regulatory capital with underlying credit risks. The proposal calls for mapping, within broad product categories, an asset's internal risk rating (summarizing the bank's internal estimates of one-year and multiyear default probabilities), expected loss in the event of default, and maturity into a risk weight for calculating the capital requirement per unit of exposure. Within the proposal, the calibration of the risk-weight mapping for corporate loans is grounded in credit risk models, while the analytical framework for residential mortgages and other retail assets is less well developed. The language of the proposal suggests that the proposed treatment of retail assets is more preliminary.

The issue of appropriate risk weights for residential mortgage loans is important for two reasons. First, residential mortgages are a major component of the loan portfolio at large banking institutions. ${ }^{10}$ As shown in Table 1, as of year-end 1999, the 25 largest banking organizations in the U.S. held 436.8 billion dollars worth of residential mortgages, representing the second largest category of loans on the balance sheet, after commercial and industrial loans. 11 Second, industry sources consistently indicate that economic capital allocations for prime residential mortgages are well below their assigned 50 percent risk weight and vary across mortgage categories. Thus, questions arise such as whether current standards encourage regulatory capital arbitrage in mortgage assets and whether the playing field should be leveled to align banks' capital costs with those of non-bank lenders. $\stackrel{12}{2}$

\section{Data and Empirical Estimates}

Our simulation procedure has two parts: calibration and implementation. Calibration involves estimating hazard models from which empirical transition probabilities can be assigned to assets in a residential mortgage portfolio conditional on stochastic risk factor realizations and portfolio characteristics. Specifically, we estimate conditional probabilities of delinquency, foreclosure, and prepayment and obtain estimates of loss-given foreclosure. Characteristics of the simulated portfolios must also be calibrated. Some variables, such as the distribution of loan amounts, are fixed throughout the analysis, while others, such as the extent of geographic diversification, are allowed to vary.

\footnotetext{
${ }^{10}$ In addition, loans sold with recourse result in off-balance sheet risk. Total recourse exposure on mortgages at the 25 largest banking organizations was 9.8 billion dollars as of year-end 1999, equal to about 20 percent of the outstanding balances of the sold mortgages. This exposure amounted to about onethird of the total recourse exposure of these organizations on all sold loans.

${ }^{11}$ Large corporate, middle-market, and small business loans are grouped together within the commercialand-industrial category.
} 
Stage two is implementation. Using the estimated coefficients from the hazard models and the estimated relationship for loss-given-foreclosure, a simulated probability distribution over a portfolio's credit losses is obtained by randomizing over risk factor realizations via Monte Carlo re-sampling from historical data. The following discussion focuses on calibration procedures; the simulation model is described in the subsequent section.

Hazard models. For the hazard estimations, we use a large and geographically diverse loan level data set from a major financial services firm that prefers anonymity. The data consist of event histories on some 47,000 first-lien, fixed-rate 30-year loans of conforming-size that were originated between 1993 and 1997 and observed through year-end 1998. The available event histories are incidence and timing of the first occurrence of 90 days delinquency (henceforth, default), incidence and timing of prepayment, and incidence and timing of foreclosure. In addition, we have original loan-to-value ratio (LTV), loan amount, and note rate; geographic location of the property (state, county, and ZIP code); and a proprietary mortgage credit score (SCORE) that ranks credit risk largely on LTV and credit history. 13 The score is on a 100-point scale with higher values representing better credit.

For about half of the loans, a FICO score $\frac{14}{14}$ also was available, enabling us to map FICO score and LTV combinations into values of SCORE. Specifically, we estimated a regression equation for SCORE, with LTV and FICO score on the right hand side (additionally including squared and cubed values of the explanatory variables and an interaction term.) Thus, for example, a FICO score of 620 combined with a loan-to-value ratio of 95 corresponds, on average, to a SCORE value of 51, while a FICO score of 720 combined with a loan-to-value ratio of 80 maps to a SCORE value of 68 . When we present our results, we use the FICO score metric, since it is widely used and understood, compared to any particular proprietary score metric.

Table 2 provides summary statistics. 1.5 Over the observation period about $2 \%$ of loans defaulted and nearly $25 \%$ of loans prepaid without defaulting. Of the loans that defaulted, about $40 \%$ ultimately went to foreclosure and about $10 \%$ ultimately prepaid. Although a majority of borrowers have loan-to-value ratios of 80 percent or lower and credit scores in the low risk range,

\footnotetext{
${ }^{12}$ Among the top mortgage lenders in the U. S. are subsidiaries of General Motors and Cendant Corporation (parent of Avis Rent-A-Car), for example.

${ }_{13}$ Additional factors, such as employment stability, are also incorporated into the score.

${ }^{14}$ FICO scores are commercially available credit scores developed by Fair, Isaac and Company and have become the credit industry standard for evaluating consumer credit risk. Scores range from 200-900 with higher values representing better credit or less risk. The national median score is 725 and every twenty points represent a doubling of the odds of default.

${ }^{15}$ SCORE was missing for 2.8 percent of the observations in the sample, and ZIP code was missing for another 1.8 percent. These observations were, of necessity, excluded from the empirical analysis below, and they were excluded from the calculation of sample mean values.
} 
a broad range of risk characteristics is represented in the sample. For instance, loan-to-value ratios at origination ranged as high as 100 percent, and more than one quarter of the sample have loan-to-value ratios of 90 percent or higher at origination. 16

We supplement loan-level information with macro-economic data over 1993-1998. We include Freddie Mac's quarterly interest rate series consisting of average contract rates for 30year, fixed rate mortgages; OFHEO's quarterly, market-level house price indices; and quarterly, county-level unemployment rate data from the Bureau of Labor Statistics (BLS). 17 In addition, we employed a measure of median household income at the ZIP code level, based on the 1990 U.S. Census.

Table 3 shows the sample mean, minimum, and maximum values of cumulative house price appreciation and total change in local unemployment rates over varying horizons (one through five years) subsequent to the date of loan origination. 18 Most borrowers are located in appreciating housing markets and declining unemployment rate labor markets. Nevertheless, a variety of conditions are present. For instance, the four-year cumulative house price appreciation ranges as low as -16 percent, and more than 10 percent of the borrowers in the sample are located in markets where house prices declined during the three-year period following origination.

The hazard models used are piecewise exponential specifications of the survival function estimated via maximum likelihood. This approach is analogous to the Poisson regression method employed by Schwartz and Torous (1993). It allows direct estimation of the conditional survival rates needed to calculate transition probabilities. It also allows hazard rates to change over time. For each event type we track the loan performance from year and quarter of origination over successive quarters indexed by $\mathrm{j}$. Within each quarter, the survival functions take the form:

$$
\log \mathrm{S}_{\mathrm{ij}}(\mathrm{t})=-t \alpha_{j} \mathrm{e}^{\beta \mathbf{x}_{\mathrm{ij}}}
$$

Here, $S_{\mathrm{ij}}(\mathrm{t})$ is the probability that loan $\mathrm{i}$ survives $\mathrm{t}$ days into quarter $\mathrm{j}$ conditional on it having survived to the beginning of quarter $\mathrm{j} ; \alpha_{\mathrm{j}}$ is a parameter determining the "baseline hazard rate" for

\footnotetext{
${ }^{16}$ Within the subset of observations for which FICO scores are available, the median FICO score is 738; the $25^{\text {th }}$ percentile is 689 ; and the $5^{\text {th }}$ percentile is 615 .

${ }^{17}$ More precisely, we used four-quarter moving averages in place of the actual quarterly unemployment rates. For non-metropolitan counties, house price indices generally are available only at the state level. Otherwise, house price indices are at the MSA level.

${ }^{18}$ Changes in local economic conditions were tracked through year-end 1998. Due to the origination and observation periods, fewer observations are available over longer time horizons.
} 
quarter $\mathbf{j}, \mathbf{x}_{\mathbf{i j}}$ a vector of covariates; and $\beta$ a coefficient vector. The associated hazard function is: 19

$$
-d / d t\left(\log \mathrm{S}_{\mathrm{ij}}(\mathrm{t})\right)=\alpha_{j} \mathrm{e}^{\beta \mathrm{x}_{\mathrm{ij}}}
$$

When estimating the survival function for defaults or foreclosures, prepayments are treated as censoring, and vice versa, following the usual method for competing risks.

There are too few events occurring in any single quarter to accurately estimate a separate baseline hazard rate for each quarter of loan life. Accordingly, we approximate the baseline hazard function piecewise by dividing the loan life into four to six periods, depending on event type. The first period is the year following origination; the intermediate periods consist of halfyear intervals, and the final period consists of all remaining quarters of observation of the loan. The baseline hazard rate is assumed to be constant across quarters within each period.

Empirical transition probabilities: current to default or prepayment. We select independent variables $\mathbf{x}_{\mathbf{i j}}$ that existing research identify as predictive of default and prepayment. Variables fall into two categories. 20 The first group includes time-varying factors affecting default and prepayment rates, which are also the risk drivers for the simulation. The second group includes control factors.

Data limitations require us to exclude a number of factors commonly associated with mortgage borrower credit risk, such as stability-of-income measures. Such omitted variables primarily are a source of concern if they are correlated with the primary risk drivers (and therefore bias the coefficient estimates) or if their distribution within our sample differs substantially from that in the typical bank portfolio (to which our model is intended to apply). We believe that the set of factors that we are able to control for suffices to allay such concerns.

\footnotetext{
${ }^{19}$ See Allison (1997) for further details.

${ }^{20}$ The theoretical option-pricing based literature has emphasized levels of borrower equity and transaction costs as the sole determinants of default probability (see, for example, Kau, et al [1992]). In that literature, mortgage default represents the rational exercise of a put option held by the borrower in response to negative equity resulting from declining house prices. Consistent with this view, virtually every empirical study identifies the level of borrower equity (or current loan-to-value ratio) as a critical determinant of default probability. Most empirical studies also find that default and prepayment probabilities depend on the spread between the original contract rate and current market rates. A number of studies emphasize socalled "trigger events" such as unemployment as a factor driving default. Recently, researchers have begun to incorporate borrower credit rating as an additional critical factor (Avery, Bostic, Calem, and Canner [1996]).
} 
Time-varying factors in both the default and prepayment equations are current loan-tovalue ratio (CLTV) and the contract interest rate on the loan relative to the market rate in quarter $\mathrm{j}$ (SPREAD). To compute CLTV, the amortized balance of the loan is divided by an updated house value using the change in the local house price index since the quarter of origination and the original appraised value. The change in the local (county) unemployment rate between the quarter of origination and quarter $\mathrm{j}$ is included as an additional time-varying factor in the default analysis (CHGUNEMP). A "burnout" variable, measuring the number of months prior to quarter $\mathrm{j}$ when the market rate was more than 100 basis points lower than the contact rate, is also included in the prepayment function.

Among the control variables, the most critical is borrower credit score (SCORE). Its omission would produce an upward bias in the estimated coefficient of the current loan-to-value ratio because borrowers with lower credit ratings tended to have higher initial LTVs and to be located in markets with less house price appreciation. 21 Further, we intend to explore how capital requirements should vary across score ranges. We also control for original loan balance (LOANAMT) and the median household income in the ZIP code where the property is located, relative to the median income in the corresponding metropolitan statistical area (MSA) or, in the case of non-MSA locations, state (RELINC). 2 Finally, we include dummy variables for two states that are over-represented in our data, together contributing about 40 percent of all observations (STATE1 AND STATE2). 23

Table 4 shows results for the default and prepayment models. Note that for the default equation, we define four segments (periods) for the baseline hazard function, and five for the prepayment equation. Preliminary analysis indicated that this permits a reasonable approximation of the baseline hazard function. Since time to event is the dependent variable, a negative sign on a coefficient estimate indicates an increase in the hazard rate and a decrease in survival probability.

Signs of coefficient estimates, all of which are statistically significant at least at the 10 percent level, are consistent with previous studies. High current loan-to-value ratio implies a higher probability of default and lower probability of prepayment during any given quarter. Borrowers with higher credit scores at origination have relatively low probabilities of default and

\footnotetext{
${ }^{21}$ In fact, exclusion of this variable results in a doubling of the coefficient on the current loan-to-value ratio in the transition-to-default equation. Moreover, since this variable is strongly associated with both defaults and prepayments, the basic assumption of the competing risks model, namely that prepayments and defaults are conditionally independent, would be violated if this variable were excluded.

${ }^{22}$ The county unemployment rate during the quarter of origination was included in an initial specification and dropped because it was found to have no explanatory power.
} 
higher probabilities of prepayment. A large spread between note rate and the current market rate is associated with high probabilities of both default and prepayment. An increase in the local market unemployment rate is associated with a higher default probability.

Empirical transition probabilities: default to foreclosure or prepayment. Here we include the time-varying risk factors CLTV and SPREAD in both equations; the credit score at origination; and the two state dummy variables. In the foreclosure equation, we also control for the original loan amount. Robustness checks indicated that other variables had virtually no explanatory power.

Results are presented in Table 5. Current loan-to-value and current interest rate spreads are both highly predictive of ultimate outcome, foreclosure or prepayment subsequent to default. As theory predicts, the smaller the amount of home equity, the more likely a delinquent loan will transition to foreclosure and the less likely it will transition to prepayment. A larger spread between note and current market rate is also associated with higher probabilities of foreclosure and prepayment.

The credit score in our data was designed primarily as a predictor of delinquency, and we had no a-priori expectations as to its relationship to transitions conditional on default. Results indicate, however, that SCORE is positively related to likelihood of prepayment and likelihood of foreclosure subsequent to default. This suggests that when borrowers in our sample who appeared to be highly creditworthy ex-ante became delinquent, they did so under unusual circumstances that made them relatively unlikely to recover, forcing them into either foreclosure or home sale.

Empirical estimates for loss-given-foreclosure. Only foreclosed loans generate losses. 4 Following OFHEO (1999), we separate loss given foreclosure into three parts. The first is the opportunity cost of funding the (non-interest earning) loan from the date of last payment until the sale of the property. Second is the net recovery associated with sale of the property; that is, the sale price of the foreclosed property less unpaid loan balance, which is usually negative. The third is transactions costs associated with the foreclosure process and property disposition. These components are summed to obtain the total loss in the event of foreclosure.

In some of our simulations, we allow for reimbursement of a proportion of the loss via private mortgage insurance for loans with LTV greater than 80 percent; i.e., there is risk sharing between lender and insurer. In these cases, we assume full reimbursement of losses up to a

\footnotetext{
${ }^{23}$ As a robustness check, we also estimated each of the four hazard models without including these dummy variables. We observed no appreciable effect on the estimated coefficients of other explanatory variables.

${ }^{24}$ In practice, lenders incur additional costs to manage delinquent accounts regardless of ultimate outcome; however, these are operating costs not credit losses.
} 
maximum of 20 percent of the unpaid principal balance if the original loan to value ratio is no greater than 90 percent and reimbursement up to 25 percent of the unpaid principal balance if the original loan-to-value ratio exceeds 90 percent.

We use the current mortgage interest rate (from the Freddie Mac quarterly series) as the funding cost. The time to default, in quarters, $\tau$ is an output of the simulation model. Since the loan is, by definition, 90 days delinquent when default occurs, the cost of funding the unpaid principal balance is calculated as interest accrued at current market rates over $\tau+1$ quarters.

Adopting the approach taken by OFHEO in calibrating its stress test for its proposed risk-based capital regulation, we set foreclosure transaction costs and property disposition costs at 5 and 10 percent of the total unpaid balance, respectively. We assume that the former is incurred at the time of foreclosure; the latter is incurred at the time of the sale and is discounted back to the date of foreclosure. Also following OFHEO, we assume property sale occurs two months after foreclosure. 26

Net recoveries are a particularly important component of loss-given-foreclosure from the perspective of analyzing economic capital, because they link loss-given-foreclosure to change in house prices. We did not have direct access to data for calibrating net recovery and its relationship to house price movements and loan characteristics, but OFHEO kindly provided an estimated regression equation based on their proprietary data (see the Appendix for further discussion.) We use these results in our simulation to estimate net recovery amounts.27

The dependent variable in the OFHEO regression equation was undiscounted net recovery as a percentage of the unpaid balance. During the simulation procedure, we recover the sale price from the imputed net recovery (Sale Price - Unpaid Balance) via the relationship:

$$
\text { Sale Price }=[(\text { Net Recovery }) *(\text { Unpaid Balance })]+\text { Unpaid Balance }
$$

Here the unpaid balance is calculated by amortizing the original amount of the loan. We then calculate discounted net recovery by discounting the sale price (using the current mortgage interest rate) to the date of foreclosure from the date of sale (assumed to be two months after

\footnotetext{
${ }^{25}$ The simulation model incorporates a small probability that foreclosure will occur well beyond one year after default, reflecting the presence of such cases within our sample. It seems probable that such cases involved at least partial recovery from an initial default followed by a recurrence of default some time later (not recorded in our data), which was then followed by the foreclosure. In such cases, calculating the funding cost for the entire period between the initial default and foreclosure would overstate the actual loss to the bank. Since it seems highly unlikely that a foreclosure process would take more than 21 months to complete, we chose to cap $\tau$ at 6 quarters for the purpose of computing funding cost.

${ }^{26}$ These calibrations are also consistent with evidence presented in Wilson (1995).
} 
foreclosure.) This recalculated net recovery amount is multiplied by minus one and added to the calculated funding and transaction costs to yield the total loss given foreclosure, denoted LGF henceforth.

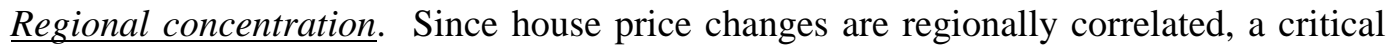
determinant of economic capital for a mortgage portfolio is the degree of geographic concentration. While large depositories hold mortgage portfolios that span multiple metropolitan areas, they tend to be at least moderately concentrated at the regional level. Table 6 summarizes the degree of concentration (defined as the proportion of the portfolio contained within one or two Census divisions) for the 100 largest banking organizations. Calculations are based on 19971999 Home Mortgage Disclosure Act (HMDA) data. 2 Loans originated or purchased during the fourth quarters are excluded due to potential underreporting of sales of these loans. 29 At most of these institutions, more than half of the total dollar amount of the portfolio is confined to a single Census division. Several of the large institutions are entirely confined to a single region. (Even among the latter, however, the portfolio spans several metropolitan areas.)

Given this pattern, we choose to conduct simulations for alternative, benchmark levels of diversification. The first benchmark is a highly regionally concentrated mortgage portfolio, defined as having loans spread across 12 MSAs but confined to a single Census division, with two thirds of the portfolio in three cities. The second benchmark is a highly diversified portfolio, based on the least geographically concentrated institutions among the institutions identified above. Here loans are spread across all 9 Census divisions and across 30 MSAs, and the two Census divisions with the largest concentration contain 40 percent and the three cities with the largest concentration contain 20 percent of the aggregate portfolio. Henceforth, we refer to the first case as the benchmark concentrated portfolio, and the second as the benchmark diversified portfolio.

Loan characteristics. We conduct a series of calculations, each involving sets of loans that are homogeneous with respect to the initial loan-to-value ratio and borrower credit score. Economic capital calculations are performed with the loan-to-value ratio set at 80, 90, and 95 percent, respectively and with SCORE calibrated (on the basis of the aforementioned mapping) to correspond to FICO scores of 620, 660, 700, and 740 respectively. These levels are

\footnotetext{
${ }^{27}$ We are extremely grateful to OFHEO, especially to David Pearl and Clifton Exeley, for their assistance.

28 Mortgages on multifamily and non-owner occupied properties, and loans classified as homeimprovement are excluded. All institutions that were subsidiaries of these organizations as of year-end 1999, including institutions acquired during the period, are included in the calculations.

${ }^{29}$ A sale that occurs in a calendar year subsequent to the year when the loan was originated or purchased is not recorded in the data.
} 
representative of sub-prime, A-, prime, and super-prime levels of credit. For each LTV level, we perform calculations with the four alternative levels of SCORE.

In order to complete the calibration required for computation of conditional transition probabilities during the simulation procedure, we still need to assign to each loan in the simulated set a balance at origination and a relative income for the neighborhood where the mortgaged property is located. This is accomplished by randomly drawing from the empirical joint distribution of loan sizes and neighborhood relative incomes.

The distribution from which we draw these loan characteristics is constructed using the same HMDA-derived database used to calibrate regional distributions. Columns 3-6 of Table 7 summarize the distribution of loan sizes within the conforming range, and the distribution of such loans by neighborhood relative income for the top 100 institutions defined above. These are the marginal distributions corresponding to the joint frequency distribution from which we draw these loan characteristics.

Out-of-sample prediction. As previously mentioned, a limitation of the data used to estimate the hazard models is that it only includes loans originated during 1993-1997, a time period when house prices in most markets were stable or increasing. Moreover, all loans are associated with a single servicing institution. To assess whether these factors may be distorting our empirical estimates, we calculated cumulative foreclosure rates implied by our estimated equations for a given FICO score and loan-to-value ratio, for loans originated in selected years, for each MSA for which an OFHEO house price series is available. ${ }^{30}$ We then averaged resulting predictions across MSAs weighting by population and compared our results to other studies. Table 8 provides the calculated average, cumulative foreclosure rates used for these comparisons.

Few studies provide information on cumulative foreclosure or default rates for conventional mortgages, and fewer still disaggregate by loan characteristics. Deng, Quigley, and Van Order (2000) report 10-year cumulative foreclosure rates on loans purchased by Freddie Mac of 2.6\% for 81-90 LTV loans and 5.1\% for greater-than-90 LTV loans originated during 19791983. While we do not know the credit score distribution of these loans, it seems reasonable to assign scores in the medium risk range to these loans, since credit scores generally are negatively correlated with loan-to-value ratios. As shown in Table 8, our simulation produces foreclosure rates similar to those reported by Deng, Quigley, and Van Order for loans with similar risk characteristics and origination dates.

\footnotetext{
${ }^{30}$ The calculations were based on a portfolio with the previously specified distribution of loan sizes and ZIP code relative incomes.
} 
The credit-rating agency Fitch IBCA (1998) reports foreclosure frequencies by LTV and FICO score for mostly non-conforming (jumbo) loans originated during 1989 through 1993 and tracked into 1997. Most of the loans (62 percent) in that study were originated in 1993; 18 percent were originated in 1992, and 11 percent in 1991. Fitch reports a base level of foreclosure for a prime grade mortgage loan ( 80 percent LTV, 700 FICO) of 0.9 percent. For lower quality credit (95 percent LTV, 660 FICO) the reported foreclosure frequency is 5.2 percent. Our results imply a higher foreclosure rate for the first category and a lower foreclosure rate for the second (assuming that the distribution by year-of-origination in each group matches the overall distribution of the sample), but differences are modest. In summary, we think our results are generally consistent with what little data is available from other studies.

\section{Simulation Model}

In this section we describe our procedure for simulating credit loss probability distributions. The basic procedure applies only to newly originated loans and assumes that parameter values are known with certainty. We also implemented an extended version of the simulation that accommodates seasoned loans and allows for uncertainty in parameter values. We describe that extension at the end of this section.

The simulation begins by randomly drawing dynamic scenarios for changes in local house prices, local unemployment rates, and interest rates over a specified horizon from the empirical distribution of these variables. In a single iteration of the simulation procedure, the selected paths for these risk factors together with each loan's risk characteristics determine each loan's transition probabilities and loss in the event of foreclosure for each quarter within the horizon.

We assume that the portfolio being simulated has a high degree of granularity, so that no single loan represents more than a negligible proportion of total portfolio. Given this assumption and a particular, realized scenario for local house prices and unemployment rates and the mortgage interest rate, we can invoke the law of large numbers and focus on the conditional expected loss rate for the portfolio. Thus, it is not necessary to simulate a performance outcome for each loan in the portfolio in each trial, but simply to calculate conditional expected loss rates for a few individual representative loans. ${ }_{1}$ We are precluded from implementing the simulation procedure strictly for an individual loan by the necessity to consider the effects of varying

31 The high degree of granularity ensures that idiosyncratic risk is diversified away. A portfolio's conditional loss rate is equal to the sum of the conditional expected losses for each loan, divided by total loan volume. For a technical discussion justifying the use of conditional expected loss rates to obtain a portfolio loss distribution, see Gordy (2000b). 
geographic locations within the bank's portfolio. We generally employ sets of 100 loans, where we assign the same loan-to-value ratio, credit score, and loan age (new origination) to each loan in the simulated set and assign distributions of loan sizes and locations as described above.

A single iteration of the simulation procedure yields an expected loss rate within the specified horizon, conditional on the drawn scenarios and specified loan characteristics. A large number of trials yield a probability distribution over loss rates for the simulated set of loans. Unless otherwise noted, we employ 5000 trials for a given run through the simulation procedure.

Selecting risk factor scenarios via re-sampling. Risk factor scenarios are generated by Monte-Carlo re-sampling, with replacement, from historical data from the 76-quarter period 1982 through 2000. As emphasized in Carey (1998), a significant advantage of the re-sampling methodology is that it avoids parametric assumptions relating to spatial and, in our context, temporal correlation of risk factors.

First, we randomly select a year and quarter during this period (the "designated quarter") to represent the year and quarter of origination of the loan. As in Carey (1998), selection of a designated quarter may be interpreted as a draw from the best available representation of the universe of possible macroeconomic environments affecting risk-factor evolution. Market interest rate scenarios are drawn directly from Freddie Mac's quarterly interest rate series beginning with the designated quarter and through the end of the specified horizon. In particular, the note rate on the loan is set at the initial rate in the series for the quarter drawn, and the path of the quarterly time series provides the series of subsequent changes in interest rates.

The next step is to draw market-level scenarios for local house prices and unemployment rates. Recall that in calibrating the simulated portfolio, we assigned each loan in the portfolio to a region (defined as a Census division) and to an MSA on the basis of a benchmark geographic distribution. For expository purposes, we refer to the MSA and region to which the loan has been assigned as the loan's "home market" and "home region," respectively. We then draw marketlevel scenarios for local house prices and unemployment rates by randomly pairing the home region with one of the nine Census divisions (the "designated region") and randomly pairing the home market with an MSA within the designated region (the "designated MSA"). The evolution of house prices in the home market is the OFHEO house price index series in the designated MSA beginning with the quarter drawn and through the end of the specified horizon. ${ }^{2}$ Similarly,

\footnotetext{
32 Obviously, designated MSAs are drawn from the set of MSAs for which a continuous OFHEO house price series exists for 1982-1998, subject to imputation of isolated missing values and the following stipulation. If an OFHEO series exists from 1985 on, we extrapolate back to the first quarter of 1982 using the state house price index. We remove extreme values for quarterly changes in house prices by placing a cap of 25 percent on the absolute value of quarterly percentage change.
} 
the evolution of unemployment rates in the home market is equated with the BLS unemployment rate series in the designated MSA beginning with the designated quarter and through the end of the specified horizon.

Note that all loans sharing the same home MSA will share the same designated MSA, and all loans sharing the same home region will share the same designated region. Together, the random selection of a designated quarter, region, and market may be interpreted as a draw from the best available representation of the universe of possible local economic environments affecting risk-factor evolution. Implicitly, this assumes that no region is more or less prone to economic stress than any other.

Calculating transition probabilities and expected loss rates. The estimated survival functions allow us to compute quarterly transition probabilities for the four types of events conditional on quarterly realizations for house prices, interest rates, and unemployment rates, via the relationship:

$$
\mathrm{p}_{\mathrm{ij}}=1-\exp \left(\mathrm{t} \alpha_{j} \mathrm{e}^{\beta \mathrm{x}_{\mathrm{ij}}}\right)
$$

Here, $\mathrm{p}_{\mathrm{ij}}$ denotes the conditional probability that loan $i$ transitions to a new state (to default, foreclosure, or prepayment, from defaulted or current) during period $j$ within $t$ days after the start of the period.

Given the set of conditional transition probabilities for each quarter within a specified horizon, the expected loss for each loan within the specified horizon is computed via recursion formulas. The appropriate horizon for computing economic capital for residential mortgages is an issue to be addressed below. In fact, it will be necessary to compare results for alternative horizons to determine which is preferable. For now, we let $H$ denote any horizon of interest, in quarters. Let $\delta$ denote a discount factor (specified below). Let TRANSI $1_{i j}$ denote the probability that a loan transitions to foreclosure in quarter $j$ conditional on default in quarter $i<j$, and let $\operatorname{TRANS}_{i j}$ denote the probability that a loan transitions to prepayment in quarter $\mathrm{j}$ conditional on default in quarter $i<j$. Given any $H$ we can recursively compute the expected loss in quarter $\mathrm{j}$ given default in quarter $\mathrm{i}$, denoted $E L G D_{i}(j)$, for $j=1, \ldots, H$, via:

(5) $\operatorname{ELGD}_{\mathrm{i}}(\mathrm{j})=\left(\mathrm{TRANS}_{\mathrm{ij}}\right)(\mathrm{LGF}), \mathrm{j}=\mathrm{H}$;

$$
\operatorname{ELGD}_{\mathrm{i}}(\mathrm{j}-1)=\left(\text { TRANS1 }_{\mathrm{ij}}\right)(L G F)+\delta\left(1-\text { TRANS1 }_{\mathrm{ij}}-\text { TRANS }_{\mathrm{ij}}\right)\left(\operatorname{ELGD}_{\mathrm{i}}(\mathrm{j})\right), \mathrm{j}<\mathrm{H} .
$$


These are simply present value formulas for cumulative expected loss within the specified horizon. Similarly, let TRANS3 $3_{i}$ denote the probability that a current loan transitions to default in quarter $i$ and let TRANS4 ${ }_{i}$ denote the probability that the loan transitions to prepayment in quarter $i$. We recursively compute the expected loss in quarter $i$, denoted $E L(i)$, for $i=1, \ldots, H$, via:

(6) $\mathrm{EL}(\mathrm{H})=0$;

$$
\mathrm{EL}(\mathrm{i})=\delta\left(\text { TRANS3 }_{\mathrm{i}}\left(\mathrm{ELGD}_{\mathrm{i}}(\mathrm{i}+1)\right)+\delta\left(\left(1-\mathrm{TRANS}_{\mathrm{i}}-\mathrm{TRANS}_{\mathrm{i}}\right)(\mathrm{EL}(\mathrm{i}+1)), \mathrm{i}<\mathrm{H} .\right.\right.
$$

A loan's initial expected loss is then given by $E L(1)$. Summing these initial expected losses for the simulated set of loans and then dividing by the total loan amount yields the expected loss rate associated with a particular iteration of the simulation process.

We still need to specify the discount factor associated with the expected loss computation. For the discount factor, we use the average 1-year treasury-bill rate over the 15year period 1984-1998, equal to 6.5 percent. The interpretation is that the bank funds losses through the sale of treasury bills (alternatively, the 1-year treasury-bill rate represents the bank's average cost of funds.)

Calculating economic capital. As described, a single iteration of the simulation procedure yields a conditional expected loss rate over a specified horizon for the simulated set of loans, and a large number of trials yield a simulated probability distribution over loss rates. Generally, we employ 5,000 trials. Standard practice is then to equate economic capital with the difference between a selected far-tail loss rate and the mean of the simulated probability distribution--a quantity termed value-at-risk. ${ }^{3}$ There are two issues to address prior to making these calculations. First, which far-tail percentile should be used; that is, what is the appropriate "solvency" standard? Second, what is the appropriate horizon for calculating conditional expected losses?

These questions are interrelated, because the selection of an appropriate far-tail percentile depends on horizon selection. In fact, the two-dimensional choice of far-tail loss rate and horizon can be reduced to a one-dimensional choice, by stipulating that the bank must hold sufficient capital for the asset to qualify for a particular agency credit rating based on the probability of exhausting capital ("insolvency") over the selected horizon. For instance, specifying a Standard \& Poor's (S\&P) BBB standard implies allocating sufficient capital to equate probability of "insolvency" with that historically associated with BBB-rated bonds over any given horizon.

33 The standard assumption is that losses up to the mean of the distribution are covered by reserves (allowances) for loan losses and margin income. 
These historical default rates are shown in Table 9, column 1, for horizons ranging from 6 to 10 years. Thus, for example, selection of a BBB standard and 8-year horizon implies a 2.5 percent insolvency probability and selection of the $97.5^{\text {th }}$ percentile of the loss distribution.

The Basel Committee's 1999 paper suggested that a reasonable benchmark for calibrating regulatory minimum capital requirements might be in the neighborhood of a BBB standard, and this is the standard we adopt for our calculations. In addition, for comparison purposes, we compute results using an S\&P A- standard. Historic cumulative default rates for A- rated bonds are shown in column 2 of Table 9.

Simulation results for 90-percent LTV loans with a FICO score of 660 in a regionally diversified portfolio, applying the BBB standard and varying the horizon from 5 to 10 years, are shown in column 3 of Table 9. For these comparisons, the last quarter eligible to be drawn is held fixed at the last quarter of 1991, the last quarter permitting calculation over horizons as long as ten years. Note that a 9-year horizon is associated with the largest capital allocation. Results for loans with the same characteristics but in a regionally concentrated portfolio are shown in column 5 of the table. For these loans, an 8-year horizon is associated with the largest capital allocation. These results have been found to hold consistently across LTV and FICO-score categories. Thus, we adopt a 9-year horizon for calculating economic capital for a regionally diversified portfolio and an 8-year horizon for a concentrated portfolio. 34

Extensions. A generalization of the procedure described accommodates both newly originated and seasoned loans and allows for uncertainty with respect to values of the estimated parameters.

Seasoning is addressed by treating the selection of an initial year and quarter as the selection of a begin-date for tracking the loan's performance, rather than as an origination date of the loan. The loan is assumed to have an initial age and initial degree of burnout (defined as the number of months since origination when the spread to market rate exceed 100 basis points.) The seasoning of the loan affects the calculated transition probabilities via the baseline hazard rate applicable to older loans and the accelerated amortization schedule influencing the current loanto-value ratio, but the simulation procedure is otherwise unchanged. For seasoned loans, we have determined that the appropriate horizon for calculating economic capital is one year shorter than for new loans: an 8-year horizon for a regionally diversified portfolio and a 7-year horizon for a concentrated portfolio.

\footnotetext{
${ }^{34}$ To maintain a consistent framework, we henceforth continue to restrict starting point draws to prior to the last quarter of 1991, unless otherwise noted.
} 
Another generalization allows for uncertainty with respect to the coefficient on the current-loan-to-value ratio in two transition probability relationships: for transitions from current to default, and for transitions from current to prepayment. Here, each iteration admits a 5 percent probability that the coefficient may deviate by 2 standard deviations from its estimated value and 33 percent probability that it may deviate by 1 standard deviation from its estimated value, in the direction of increasing likelihood of default and decreasing likelihood of prepayment. It is assumed that these deviations are perfectly correlated; i.e., any special circumstances that increase default frequency will also reduce prepayment frequency. For example, a deviation from the average relationship between house price appreciation and frequency of default may be due to an increase in the proportion of homes with declining market values holding the mean rate of appreciation constant, and this is likely to also imply a reduction in prepayment frequency.

\section{Simulation Results}

Initially, the simulations were conducted under the assumption that no loans were covered by private mortgage insurance. This is typically the case, for example, for sub-prime lending. Toward the end of this section, we discuss how results change when this assumption is relaxed.

Results from application of the basic model (no parameter uncertainty) to derive economic capital allocations for newly originated mortgages are shown in Table 10. The first column indicates LTV and FICO score category. The second column provides, as a benchmark risk measure, the 8-year cumulative foreclosure rate obtained via application of the simulation procedure in the case of a diversified portfolio; the third indicates expected discounted cumulative loss rate. The remaining columns provide the capital allocations under BBB and Astandards for the two types of portfolios. In the case of a regionally diversified portfolio, the calculated economic capital allocations are consistently below the 2 percent ( 4 percent for 95 LTV) regulatory minimum requirement. Capital allocations for the regionally concentrated portfolio are consistently about double those for the diversified portfolio and, for higher risk classes, exceed the regulatory standard. Substantial differences by LTV and FICO score are evident, where a higher expected loss rate is generally associated with higher capital.

It is worth noting that the tails of the simulated loss probability distributions extend substantially beyond the BBB and A- thresholds. For example, the $99^{\text {th }}$ percentile loss rate for the $90 \mathrm{LTV}, 620$ FICO category is 36 basis points larger than the BBB capital allocation (183 basis points) in the case of a regionally diversified portfolio, and 85 basis points larger than the BBB capital allocation (374 basis points) in the case of a regionally concentrated portfolio. 
Not surprisingly, close examination reveals that tail loss rates are generated primarily by selection of origination quarters and regions tied to major housing market declines. In the case of a concentrated portfolio, they are generated overwhelmingly by selection of the New England division and origination quarters in 1989-1991, with city concentrations having a secondary role. Of the 150 worst outcomes, 95 percent involve selection of New England in 1989, 1990, or 1991, with a disproportionate number of outcomes involving concentrations in Barnstable, Boston, Bridgeport, or Brockton. A lone outcome involved selection of the Middle Atlantic region with concentrations in Bergen-Passaic, Allentown, New York City, and Dutchess County. The remaining worst outcomes involve selection of the Pacific division in 1991. Each of the latter exhibits a concentration in three or four cities that had a substantial housing market declines and/or extended period of high unemployment. These cities include some obvious candidates such as Los Angeles, Orange County, Modesto, and Riverside, as well as some less obvious ones such as Anchorage and Bremerton (Washington), where unemployment increased sharply while house prices were relatively stable. The latter observation suggests that the marginal statistical significance of the change-in-unemployment-rate variable in the estimated hazard models understates its economic significance.

In the case of a diversified portfolio, tail loss rates are generated primarily by an assignment of origination quarters in 1989-1991 with concentrations in the New England division and/or the Pacific division. In many cases, the tail outcomes involve secondary concentrations in the Mid-Atlantic and West South Central divisions. 35 Individual city assignments appear to play a relatively unimportant role in generating tail outcomes for diversified portfolios, with concentrations in cities such as Allentown, Los Angeles, Modesto, and New Orleans appearing to be a factor in only a handful of cases among the 150 worst outcomes.

Extended model results. Application of the generalized simulation procedure to derive economic capital allocations for newly originated mortgages (i.e., allowing for variability in default and prepayment relationships to current the loan-to-value) yields the results in Table 11. Capital allocations under the BBB standard are generally 30-40 percent higher for a regionally diversified portfolio and 8-13 percent higher for a regionally concentrated portfolio, compared to those shown in Table 10. Nevertheless, the calculated economic capital allocations for a

\footnotetext{
${ }^{35}$ Many cities in the West South Central division experienced an extended increase in unemployment, while house prices there were relatively stable.
} 
regionally diversified portfolio remain below the 2 percent ( 4 percent for 95 LTV) regulatory minimum requirement, with the exception of the 90 LTV / 620 FICO category

Application of the generalized simulation procedure to derive economic capital allocations for seasoned mortgages (again allowing for variability in default and prepayment relationships to current the loan-to-value) yields the results exhibited in table 12 . These calculations assume loans were subject to a prior "burnout" period of 12 months when the market interest rate was at least 100 basis points below the note rate. The BBB capital allocations for a seasoned mortgage are generally $25-30$ percent higher given a regionally diversified portfolio, and 15-20 percent higher given a regionally concentrated portfolio, compared to those for a newly originated mortgage with the same LTV and FICO score. Again, the calculated economic capital allocations for a regionally diversified portfolio remain below the 2 percent ( 4 percent for 95 LTV) regulatory minimum requirement, with the exception of the 90 LTV / 620 FICO category.

Expected losses are also substantially higher for seasoned mortgages, posing the question whether the relationship between expected loss and capital is essentially the same for seasoned loans as for new loans. Figure 1 plots economic capital under a BBB standard in relation to expected losses based on the results in Tables 11 and 12, along with additional results for seasoned (3-year old) mortgages without prior "burnout." These plots suggest several observations. First, capital allocations for seasoned loans are lower than for new loans holding expected loss constant, although for a regionally diversified portfolio the differences in general are small. Second, for each level of regional diversification, a single relationship between expected loss and capital appears to be applicable to all seasoned loans, regardless of the degree of prior burnout. That is, given expected loss and the degree of regional diversification, prior burnout is irrelevant to determining capital. Finally, for both seasoned and new loans and either degree of regional diversification, the relationship between expected loss and capital is close to linear. 37

Mortgage insurance. Typically, prime high-LTV loans are originated with private mortgage insurance; indeed, they must be if intended for sale to the GSEs. We also have conducted simulations allowing for full reimbursement of losses up to the previously specified maximums (up to 20 percent of the unpaid principal balance for 90 LTV mortgages and up to 25 percent for 95 LTV mortgages), restricting attention to new loans. Given either degree of

\footnotetext{
${ }^{36}$ To the extent that loans to borrowers with FICO scores of 620 or below are explicitly tied to sub-prime lending programs, they may be required to hold additional capital based on supervisory assessments under the current regulatory regime.
} 
regional diversification, private mortgage insurance reduces BBB capital allocations by 36-39 percent in the 90 LTV categories and by 25-33 percent in the 95 LTV categories. Nevertheless, in the case of a regionally concentrated portfolio, BBB economic capital allocations continue to exceed the current regulatory requirement for a number of the higher risk categories, particularly because the regulatory requirement is only 2 percent for 95 LTV loans with private mortgage insurance.

Figure 2 plots economic capital under a BBB standard in relation to expected losses for loans originated with and without private mortgage insurance, restricting attention to the 90 and 95 LTV categories. The plots indicate that capital allocations for insured loans are somewhat higher than for non-insured loans holding expected loss constant. This reflects the fact that mortgage insurance reduces expected losses more than it reduces losses in the tail, due to the caps on reimbursements.

Robustness Tests. We have explored robustness of the results by repeating some of our simulations with alternative calibrations. Three types of re-calibrations were considered: increasing the number of iterations from 5000 to 10000 , enlarging the size of the simulated portfolio from 100 to 1000 loans, and modifying the region definitions.

Doubling the number of iterations appears to have a negligible effect in the direction of slightly reducing economic capital allocations under a BBB or A- standard. 9 Increasing the size of the simulated portfolio also appears to have a negligible effect, generally changing the economic capital allocation by only a few basis points. The largest changes from enlarging the portfolio were associated with regional concentration and higher risk categories and involved reductions of about 5 percent of the originally calculated capital allocations.

Our final robustness exploration involved substituting regions defined by Case (2001) for the Census divisions. These alternative region definitions were constructed based on an analysis of commonalities in housing market fundamentals across MSAs. While they coincide roughly with Census divisions, they exhibit some important distinctions such as combining New England with the Mid-Atlantic Census division. Primarily as a consequence of the latter aggregation, use

\footnotetext{
${ }^{37}$ Minor deviations from the linear relationship, such as slightly higher capital for 95 LTV and 700 FICO score compared to $90 \mathrm{LTV}$ and 660 FICO score, are attributable to loss-given foreclosure being somewhat more pro-cyclical for higher-LTV loans.

${ }^{38}$ We calculated capital allocations for newly originated loans with private mortgage insurance, using the generalized model incorporating parameter uncertainty, comparable to the calculations underlying table 11 . In the case of a regionally diversified portfolio and in order of increasing FICO score, economic capital allocations under a BBB standard are 1.5, 1.15, 0.8, and 0.52 percent for 90 LTV categories and 2.54, 1.9, 1.33 , and 0.96 percent for $95 \mathrm{LTV}$ categories. In the case of a regionally concentrated portfolio, they are $2.70,1.97,1.35,0.94$ for $90 \mathrm{LTV}$ categories and 4.36, 3.36, 2.32, and 1.58 for $95 \mathrm{LTV}$ categories.
} 
of these regions in place of Census divisions lower capital requirements. However, the differences were not large: a 5-10 percent reduction in BBB capital allocations for a regionally diversified portfolio and a 10-15 percent reduction for a regionally concentrated portfolio.

\section{Conclusions}

We have developed and implemented a method for calculating risk-based capital requirements for mortgage loans held in portfolio by financial intermediaries. Our method uses a non-parametric simulation procedure following Carey [1998] together with standard hazard models of mortgage loan performance that are based on recent empirical data. The values reported are essentially credit VAR measures, i.e. the excess of far tail loss probabilities over expected values. Results seem reasonable and illustrate the benefits of geographic diversification, together with the increased credit risk associated with high LTV and/or sub-prime lending.

We find that the current regulatory standards for capital are too high in most cases. A conspicuous exception, however, is in regionally concentrated sub-prime lending. Regionally concentrated portfolios require one-and-one-half to two times the economic capital of diversified portfolios. Our results are robust to the size of the simulated portfolio, the number of simulations runs, and regional definitions. We hope in future research to extend the approach developed here to adjustable-rate and jumbo non-conforming asset categories.

Implementation of reduced capital requirements for mortgage assets would likely have significant impact on capital markets. Incentives for regulatory capital arbitrage would be reduced and mortgage assets would come to be more widely held by banks of thrifts. Moreover, a reduction in concentration of ownership might well reduce current pressures for full privatization of the GSEs. Most importantly, the underlying economic risk characteristics of the assets held would more closely correspond to regulatory capital requirements.

\footnotetext{
${ }^{39}$ The farther tail of the loss distribution is made wider, however, resulting, for instance, in a much larger maximum portfolio loss rate in some cases.
} 


\section{Appendix: Regression Analysis of Net Recovery in the Event of Foreclosure}

A regression equation relating net recovery on sale of a foreclosed property (REO sale) to characteristics of the loan and housing market conditions was provided by OFHEO. The sample consisted of 15- or 30-year first-lien, fixed-rate mortgages financing 1-4 family owner-occupied properties, originated 1989-1997 and foreclosed prior to year-end 1999. The sample was very large, with tens of thousands of foreclosed loans, but contained only loans of conforming size (the maximum loan size was $\$ 250,000$.) Due to the proprietary nature of the database, we are unable to provide detailed descriptive statistics or regression results.

The data included dollar amounts from the sale of the foreclosed properties and unpaid balance at the date of foreclosure (UPB), from which the percentage net recovery on the sale of a foreclosed property was calculated as:

$\%$ Net Recovery $=100 \times$ [Gross Sale Proceeds - UPB] $/[$ UPB]

This was regressed on the current loan to value ratio as approximated using the unpaid principal balance, original appraised value, and local rate of house price appreciation between the dates of origination and foreclosure. A number of control variables were included, such as the original loan-to-value ratio and original loan amount.

The mean percentage net recovery in the sample was about $-7 \%$. Percentage net recovery was found to increase with the rate of local house price appreciation, consistent with larger recoveries when the relative value of the collateral is higher. Figure A-1 plots the predicted value of \%_NET_RECOV from our estimated regression equation in relation to APPREC, with original loan-to-value ratio (LTV) alternatively set equal to 80,90 , and $95 \%$ and with other variables set equal to their sample mean values. The relationships suggest a substantial impact of housing market cycles on net recovery rates. For instance, for loans with LTV=80, a 25 percent decline in house prices (a reasonable stress scenario) is associated with a percentage net recovery of $-25 \%$, while zero appreciation is associated with a percentage net recovery of $-2 \%$. 


\section{References}

Allsion, Paul D., Survival Analysis Using the SAS ${ }^{\circledR}$ System, Cary, NC: SAS Institute, Inc. (1997).

Ambrose, Brent A. and Michael LaCour-Little "Prepayment Performance of Adjustable Rate Mortgages Subject to Initial Year Discounts: Some New Evidence" Real Estate Economics 29 (2001), pp. 305-328.

Avery, Robert B., Raphael W. Bostic, Paul S. Calem, and Glenn B. Canner, "Credit Risk, Credit Scoring, and the Performance of Home Mortgages," Federal Reserve Bulletin 82 (1996), pp. 621648.

Basel Committee on Banking Supervision, "Consultative Paper on a New Capital Adequacy Framework.” Bank for International Settlements, Basel, Switzerland (June 1999).

Berger, Allen N., Richard J. Herring, and Georgio P. Szego, "The Role of Capital in Financial Institutions," Journal of Banking \& Finance 19 (1995), pp. 393-430.

Calem, Paul S., and Rafael Rob, "The Impact of Capital-Based Regulation on Bank RiskTaking," Journal of Financial Intermediation 8 (1999), pp. 317-352.

Cambell, Tim and J. Kimball Dietrich, "The Determinants of Default on Insured Conventional Residential Mortgage Loans,” Journal of Finance 38 (1983), pp. 1569-1581.

Carey, Mark, "Credit Risk in Private Debt Portfolios," Journal of Finance 53 (1998), pp. 13631386.

Case, Bradford, "Co-Movements in U.S. House Price Appreciation Patterns," draft, Board of Governors of the Federal Reserve System (January 2001).

Crouhy, Michel, Dan Galai, and Robert Mark, "A Comparative Analysis of Current Credit Risk Models," Journal of Banking and Finance 24 (2000), pp. 59-117.

Cunningham, Donald F. and Charles A. Capone, "The Relative Termination Experience of Adjustable to Fixed-Rate Mortgages," Journal of Finance 45 (2000), pp. 1687-1703.

Deng, Yongheng, John M. Quigley, and Robert Van Order, "Mortgage Terminations, Heterogeneity and the Exercise of Mortgage Options," Econometrica 68 (2000), pp. 275-307.

Diamond, Douglas W., and Raghuram G. Rajan, “A Theory of Bank Capital," Journal of Finance 55 (2000), pp. 2431-2465.

Fitch, IBCA, Duff \& Phelps, "Residential Mortgage-Backed Securities Criteria" (1998).

Gordy, Michael B., "A Comparative Anatomy of Credit Risk Models," Journal of Banking and Finance 24 (2000a), pp. 119-149.

Gordy, Michael B., “A Risk-Factor Model Foundation for Ratings-Based Capital Rules,” Board of Governors of the Federal Reserve System (2000b). 
Greenspan, Alan, "The Role of Capital in Optimal Banking Supervision and Regulation," Federal Reserve Bank of New York Policy Review 4 (1998), pp. 163-168.

Jones, David, "Emerging Problems with the Basel Capital Accord: Regulatory Capital Arbitrage and Related Issues," Journal of Banking \& Finance 24 (2000), pp. 35-58.

Kau, James B., Donald Keenan, Walter Mueller, and J. Epperson, "A Generalized Valuation Model for Fixed-Rate Residential Mortgages," The Journal of Money, Credit, and Banking 24 (1992), pp. 279-299.

Modigliani, Franco, and M. Miller, "The Cost of Capital, Corporation Finance, and the Theory of Investment. American Economic Review (1958), pp. 261-297.

Quercia, Roberto G. and Michael A. Stegman "Residential Mortgage Default: A Review of the Literature". Journal of Housing Research Vol. 3, No. 2 (1992): 341-376.

Quigley, John M., and Robert Van Order, "Defaults on Mortgage Obligations and Capital Requirements for U.S. Savings Institutions," Journal of Public Economics 44 (1991), pp. 353369.

Santos, Joao A. C., "Bank Capital Regulation in Contemporary Banking Theory: A Review of the Literature," Financial Markets, Institutions, \& Instruments 10 (2001), pp. 41-84.

Schwartz, Eduardo S., and Walter N. Torous, "Mortgage Prepayment and Default Decisions: A Poisson Regression Approach," Journal of the American Real Estate and Urban Economics Association 21 (1993), pp. 431-449.

Shrieves and Dahl, "The Relationship Between Risk and Capital in Commercial Banking", Journal of Banking \& Finance 16 (1992), pp. 439-457.

Standard and Poor's, Ratings Performance 1999: New York: Standard \& Poor's Corporation (February 2000).

Von Furstenburg, George, "The Default Risk on FHA-Insured Home Mortgages," Journal of Finance 37 (1969), pp. 169-183.

Wilson, Donald G., "Residential Loss Severity in California: 1992-1995," Journal of Fixed Income" (December 1995), pp. 35-48. 
Table 1: Composition of the Aggregate Domestic Loan Portfolio of the 25 Largest Banking Organizations in the U.S. (as of Dec. 31, 1999)

\begin{tabular}{|l|c|c|}
\hline \multicolumn{1}{|c|}{ Category* } & \$ Amount (billions) & Percent \\
\hline Residential Mortgages & 436.38 & 26.0 \\
\hline Multifamily Mortgages & 21.83 & 1.2 \\
\hline Farm Mortgages & 6.38 & 0.4 \\
\hline Construction & 58.68 & 3.2 \\
\hline Commercial Mortgages & 164.08 & 9.0 \\
\hline Commercial and Industrial & 524.14 & 28.9 \\
\hline Consumer & 278.88 & 15.4 \\
\hline Lease Financing & 129.44 & 7.1 \\
\hline Other & 203.12 & 9.8 \\
\hline Total & $1,814.37$ & 100.0 \\
\hline
\end{tabular}

* Residential mortgage category consists of loans secured by 1-4 family properties; multifamily consists of loans secured by properties with 5 or more units; farm consists of loans secured by farmland.

Source: Consolidated Reports of Condition and Income (FR-Y9C)

Table 2: Means of Variables

\begin{tabular}{|l|c|}
\hline \multicolumn{1}{|c|}{ Variable } & Mean \\
\hline Contract interest rate (\%) & 7.8 \\
\hline Original LTV (\%) & 74.0 \\
\hline $\begin{array}{l}\text { \% originated with private } \\
\text { mortgage insurance }\end{array}$ & 21.7 \\
\hline Overall default rate (\%) & $\mathbf{2 . 2}$ \\
\hline $\begin{array}{l}\text { Overall foreclosure } \\
\text { Rate (\%) }\end{array}$ & $\mathbf{0 . 8 5}$ \\
\hline $\begin{array}{l}\text { Overall prepayment } \\
\text { rate (\%) }\end{array}$ & $\mathbf{2 2 . 1}$ \\
\hline Credit score & $\mathbf{6 9 . 5}$ \\
\hline Original loan amount & $\mathbf{1 0 8 , 1 0 0}$ \\
\hline
\end{tabular}


Table 3: Summary Statistics for Market Variables

\begin{tabular}{|c|c|c|c|c|}
\hline Variable & $\begin{array}{c}\text { No. of } \\
\text { Observations }\end{array}$ & Mean & Minimum & Maximum \\
\hline $\begin{array}{l}\text { 1-year house price } \\
\text { appreciation rate }\end{array}$ & 45,922 & $2.1 \%$ & $-11.7 \%$ & $17.3 \%$ \\
\hline $\begin{array}{l}\text { 1-year total change } \\
\text { in } \% \text { unemployed }\end{array}$ & 45,922 & $-0.57 \%$ & $-5.5 \%$ & $3.8 \%$ \\
\hline $\begin{array}{l}\text { 2-year cumulative } \\
\text { price appreciation } \\
\text { rate }\end{array}$ & 44,687 & $5.7 \%$ & $-15.0 \%$ & $31.9 \%$ \\
\hline $\begin{array}{l}\text { 2-year total change } \\
\text { in } \% \text { unemployed }\end{array}$ & 44,687 & $-1.0 \%$ & $-8.0 \%$ & $5.7 \%$ \\
\hline $\begin{array}{l}\text { 3-year cumulative } \\
\text { price appreciation } \\
\text { rate }\end{array}$ & 34,170 & $7.3 \%$ & $-14.7 \%$ & $46.0 \%$ \\
\hline $\begin{array}{l}\text { 3-year total change } \\
\text { in } \% \text { unemployed }\end{array}$ & 34,170 & $-1.4 \%$ & $-7.3 \%$ & $5.4 \%$ \\
\hline $\begin{array}{l}\text { 4-year cumulative } \\
\text { price appreciation } \\
\text { rate }\end{array}$ & 27,407 & $10.4 \%$ & $-16.0 \%$ & $53.5 \%$ \\
\hline $\begin{array}{l}\text { 4-year total change } \\
\text { in } \% \text { unemployed }\end{array}$ & 27,407 & $-1.8 \%$ & $-7.0 \%$ & $3.5 \%$ \\
\hline $\begin{array}{l}\text { 5-year cumulative } \\
\text { price appreciation } \\
\text { rate }\end{array}$ & 19,928 & $13.9 \%$ & $-11.6 \%$ & $62.6 \%$ \\
\hline $\begin{array}{l}\text { 5-year total change } \\
\text { in \% unemployed }\end{array}$ & 19,928 & $-2.5 \%$ & $-8.2 \%$ & $2.6 \%$ \\
\hline
\end{tabular}


Table 4: Survival Analysis Results

Transitions to Default and Prepayment from Current

(Chi Square Statistics in Parenthesis)

\begin{tabular}{|c|c|c|}
\hline & $\begin{array}{c}\text { Dependent variable: } \log \text { of } \\
\text { duration to default }\end{array}$ & $\begin{array}{l}\text { Dependent variable: } \log \text { of } \\
\text { duration to prepayment }\end{array}$ \\
\hline INTERCEPT & $8.467(240.8)^{* * *}$ & $16.50(7562.1)^{* * *}$ \\
\hline CLTV & $-0.0257(61.4)^{* *}$ & $0.0081(147.2)^{* *}$ \\
\hline BURNOUT & & $0.0153(70.5)^{* * *}$ \\
\hline CHGUNEMP & $\begin{array}{c}-0.0827(3.54) \\
\end{array}$ & \\
\hline SPREAD & $-1.992(48.0) * *$ & $-7.154(2596.1)^{* *}$ \\
\hline SCORE & $0.0828(730.5) * *$ & $-0.0102(98.1)^{* * *}$ \\
\hline LOANAMT & $0.0039(17.3)^{* * *}$ & $-0.0062(663.7) * *$ \\
\hline RELINC & $0.0026(4.28)^{*}$ & $-0.0019(35.2) * *$ \\
\hline PERIOD1 & $1.408(163.3)^{* * *}$ & $1.342(1414.5)^{* * *}$ \\
\hline PERIOD2 & $0.652(37.3)^{* *}$ & $0.5476(262.9) * *$ \\
\hline PERIOD3 & $0.4894(21.5)^{* * *}$ & $0.3827(130.5)^{* *}$ \\
\hline PERIOD4 & & $0.2367(50.4)^{* * *}$ \\
\hline \begin{tabular}{|l} 
STATE1 \\
\end{tabular} & $0.5482(45.6)^{* * *}$ & $0.6239(648.3)^{* *}$ \\
\hline STATE2 & $0.3688(14.3) * *$ & $0.2925(71.5)^{* * *}$ \\
\hline
\end{tabular}

** Significant at the 1 percent level

* Significant at the 5 percent level 
Table 5: Survival Analysis Results

Transitions to Foreclosure and Prepayment from Default

(Chi Square Statistics in Parenthesis)

\begin{tabular}{|c|c|c|}
\hline & $\begin{array}{c}\text { Dependent variable: } \log \text { of } \\
\text { duration to default }\end{array}$ & $\begin{array}{l}\text { Dependent variable: } \text { log of } \\
\text { duration to prepayment }\end{array}$ \\
\hline INTERCEPT & $9.447(113.6) * *$ & $14.95(64.9) * *$ \\
\hline CLTV & $-0.0153(8.33)^{* *}$ & $0.0229(9.52)^{* *}$ \\
\hline LOANAMT & $0.0025(2.17)$ & \\
\hline SPREAD & $\begin{array}{l}-0.3841(0.77) \\
\end{array}$ & $-4.721(25.1)^{* * *}$ \\
\hline SCORE & $-0.0204(14.0)^{* *}$ & $-0.0367(10.8)^{* * *}$ \\
\hline PERIOD1 & $0.4475(1.46)$ & $-1.169(1.31)$ \\
\hline PERIOD2 & $0.0300(0.01)$ & $-0.7711(0.55)$ \\
\hline PERIOD3 & $0.2127(0.31)$ & $0.0303(0.00)$ \\
\hline PERIOD4 & $0.5100(1.59)$ & $-0.4603(0.18)$ \\
\hline PERIOD5 & $0.6794(2.66)$ & $-0.3605(0.11)$ \\
\hline STATE1 & $0.0975(0.43)$ & $-0.0959(0.12)$ \\
\hline STATE2 & $-0.7745(27.7)^{* *}$ & $-0.9125(9.55)^{* *}$ \\
\hline
\end{tabular}

** Significant at the 1 percent level

* Significant at the 5 percent level 
Table 6: Degree of regional concentration of mortgage portfolios of large depository institutions (based on 100 largest mortgage-lending institutions.)

\begin{tabular}{|l|c|}
\hline Degree of Regional Concentration & $\begin{array}{l}\text { Number of } \\
\text { Institutions }\end{array}$ \\
\hline $\begin{array}{l}\text { More than } 99 \% \text { of loan volume in a } \\
\text { single Census division }\end{array}$ & 10 \\
\hline $\begin{array}{l}\text { Less than } 99 \% \text { but more than } 75 \% \\
\text { in one Census division }\end{array}$ & 25 \\
\hline $\begin{array}{l}\text { Less than } 75 \% \text { in any one but more } \\
\text { than } 75 \% \text { in two Census divisions }\end{array}$ & 19 \\
\hline $\begin{array}{l}\text { Less than } 75 \% \text { but more than } 50 \% \\
\text { in two Census divisions }\end{array}$ & 37 \\
\hline $\begin{array}{l}\text { Less than } 50 \% \text { in any two Census } \\
\text { divisions }\end{array}$ & 9 \\
\hline
\end{tabular}

Source: 1997-1999 Home Mortgage Disclosure Act data 
Table 7: Aggregate Distribution of Conforming-Size Residential Mortgages Retained by the 25 Largest Portfolio Lenders, by Neighborhood Income and Size

Aggregate distribution by Census division, tract relative income and loan size, based on 1997-1999 HMDA data (4 ${ }^{\text {th }}$ quarters excluded), of loans of size $<\$ 250,000$ originated or purchased and retained in the portfolio

\begin{tabular}{|c|c|c|c|c|c|}
\hline $\begin{array}{c}\text { Census } \\
\text { division }\end{array}$ & $\begin{array}{c}\text { Percent of } \\
\text { total \$ } \\
\text { amount of } \\
\text { loans }\end{array}$ & $\begin{array}{c}\text { Tract } \\
\text { relative } \\
\text { income } \\
\text { category* }\end{array}$ & $\begin{array}{c}\text { Percent of } \\
\text { total } \\
\text { number of } \\
\text { loans }\end{array}$ & $\begin{array}{c}\text { Loan size } \\
\text { category }\end{array}$ & $\begin{array}{c}\text { Percent } \\
\text { of total } \\
\text { number } \\
\text { of loans }\end{array}$ \\
\hline 1 & $3 \%$ & $<80 \%$ & 10.0 & $<\$ 25,000$ & 18.2 \\
\hline 2 & $12 \%$ & $80-100 \%$ & 9.7 & $\$ 25-50,000$ & 20.5 \\
\hline 3 & $21 \%$ & $100-120 \%$ & 17.5 & $\$ 50-75,000$ & 14.3 \\
\hline 4 & $4 \%$ & $120-140 \%$ & 26.8 & $\$ 75-100,00$ & 12.2 \\
\hline 5 & $13 \%$ & $140-160 \%$ & 22.7 & $\$ 100-125,00$ & 9.5 \\
\hline 6 & $2 \%$ & $>160 \%$ & 13.3 & $\$ 125-150,000$ & 7.8 \\
\hline 7 & $6 \%$ & -- & -- & $\$ 150-175,000$ & 5.4 \\
\hline 8 & $8 \%$ & -- & -- & $\$ 175-200,000$ & 4.5 \\
\hline 9 & $31 \%$ & -- & -- & $>\$ 200,000$ & 7.6 \\
\hline
\end{tabular}

* Ranges are based on tract median income relative to the median income of the metropolitan area (or, for non-MSA tracts, the median income of all non-metropolitan counties in the state) where the tract is located. 
Table 8: Predicted Cumulative Default and Foreclosure Rates

Population-weighted average cumulative default and foreclosure rates across MSAs by origination year and loan characteristics

\begin{tabular}{|l|l|c|c|c|}
\hline $\begin{array}{l}\text { Origination } \\
\text { Year }\end{array}$ & $\begin{array}{l}\text { Performance } \\
\text { Horizon }\end{array}$ & $\begin{array}{l}\text { Loan-to- } \\
\text { Value Ratio }\end{array}$ & FICO Score & $\begin{array}{l}\text { Cumulative } \\
\text { Foreclosure } \\
\text { Rate (\%) }\end{array}$ \\
\hline 1982 & 10 years & 90 & 700 & 2.5 \\
\hline 1982 & 10 years & 90 & 680 & 4.8 \\
\hline 1993 & 5 years & 95 & 660 & 3.2 \\
\hline 1992 & 6 years & 95 & 660 & 5.6 \\
\hline 1991 & 7 years & 95 & 660 & 8.3 \\
\hline 1993 & 5 years & 80 & 700 & 0.9 \\
\hline 1992 & 6 years & 80 & 700 & 1.4 \\
\hline 1991 & 7 years & 80 & 700 & 2.0 \\
\hline
\end{tabular}

Table 9: Performance Horizon Comparisons

Historic default rates on $B B B$ and $A$ - bonds and economic capital calculations under a $B B B$ standard $(L T V=90$ and $F I C O=660)$

\begin{tabular}{|l|c|c|c|c|}
\hline Horizon & $\begin{array}{c}\text { BBB bond } \\
\text { cumulative } \\
\text { default rate* } \\
(\boldsymbol{\%})\end{array}$ & $\begin{array}{c}\text { A- bond } \\
\text { cumulative } \\
\text { default rate* } \\
(\boldsymbol{\%})\end{array}$ & $\begin{array}{c}\text { Economic capital: } \\
\text { regionally } \\
\text { diversified } \\
\text { portfolio }(\boldsymbol{\%})\end{array}$ & $\begin{array}{c}\text { Economic capital: } \\
\text { regionally } \\
\text { concentrated } \\
\text { portfolio }(\boldsymbol{\%})\end{array}$ \\
\hline 5 years & 1.65 & 0.70 & 1.03 & 2.16 \\
\hline 6 years & 1.94 & 1.00 & 1.17 & 2.53 \\
\hline 7 years & 2.20 & 1.40 & 1.28 & 2.72 \\
\hline 8 years & 2.50 & 1.73 & 1.34 & 2.83 \\
\hline 9 years & 2.82 & 2.03 & 1.37 & 2.80 \\
\hline 10 years & 3.18 & 2.20 & 1.36 & 2.78 \\
\hline
\end{tabular}

* Source: Standard and Poors 
Table 10: Economic Capital for Newly Originated Loans

Simulated capital charges by LTV and credit score, under BBB and A- solvency standards

\begin{tabular}{|c|c|c|c|c|c|c|}
\hline \multirow{3}{*}{\begin{tabular}{|c} 
LTV $(\%) /$ \\
FICO- \\
Score \\
$80 / 620$ \\
\end{tabular}} & \multirow{3}{*}{$\begin{array}{c}\begin{array}{c}\text { 8-year expected } \\
\text { foreclosure rate } \\
(\%) *\end{array} \\
4.36\end{array}$} & \multirow{3}{*}{$\begin{array}{c}\begin{array}{c}\text { 8-year expected } \\
\text { discounted } \\
\text { cumulative loss } \\
\text { rate }(\%) *\end{array} \\
1.02\end{array}$} & \multicolumn{2}{|c|}{$\begin{array}{c}\text { Economic capital (\%): } \\
\text { regionally diversified } \\
\text { portfolio }\end{array}$} & \multicolumn{2}{|c|}{$\begin{array}{c}\text { Economic capital (\%): } \\
\text { regionally } \\
\text { concentrated portfolio }\end{array}$} \\
\hline & & & $B B B$ & $A-$ & BBB & $A-$ \\
\hline & & & 0.87 & 0.94 & 1.78 & 1.98 \\
\hline 80 / 660 & 2.91 & 0.68 & 0.58 & 0.63 & 1.21 & 1.35 \\
\hline $80 / 700$ & 1.92 & 0.45 & 0.38 & 0.41 & 0.82 & 0.89 \\
\hline 80 / 740 & 1.25 & 0.29 & 0.25 & 0.27 & 0.53 & 0.58 \\
\hline 90 / 620 & 7.80 & 2.12 & 1.83 & 1.96 & 3.74 & 4.19 \\
\hline 90 / 660 & 5.77 & 1.56 & 1.37 & 1.46 & 2.83 & 3.16 \\
\hline $90 / 700$ & 3.89 & 1.05 & 0.92 & 0.99 & 1.94 & 2.16 \\
\hline $90 / 740$ & 2.58 & 0.70 & 0.61 & 0.66 & 1.31 & 1.46 \\
\hline 95 / 620 & 10.62 & 3.03 & 2.63 & 2.81 & 5.35 & 5.96 \\
\hline 95 / 660 & 7.96 & 2.26 & 1.99 & 2.13 & 4.11 & 4.61 \\
\hline $95 / 700$ & 5.44 & 1.54 & 1.37 & 1.47 & 2.89 & 3.23 \\
\hline $95 / 740$ & 3.65 & 1.04 & 0.92 & 0.99 & 1.97 & 2.19 \\
\hline
\end{tabular}

*Assumes diversified portfolio. 


\section{Table 11: Economic Capital for Newly Originated Loans—Extended Model}

Simulated expected loss rates, foreclosure rates and capital charges by LTV and credit score, under BBB and A- solvency standards

\begin{tabular}{|c|c|c|c|c|c|c|}
\hline $\begin{array}{c}\text { LTV }(\%) / \\
\begin{array}{c}\text { FICO- } \\
\text { Score }\end{array}\end{array}$ & $\begin{array}{c}\text { 8-year expected } \\
\text { foreclosure rate } \\
\text { (\%)* }\end{array}$ & $\begin{array}{c}\text { 8-year expected } \\
\text { discounted } \\
\text { cumulative loss } \\
\text { rate }(\%) *\end{array}$ & \multicolumn{2}{|c|}{$\begin{array}{c}\text { Economic capital (\%): } \\
\text { regionally diversified } \\
\text { portfolio }\end{array}$} & \multicolumn{2}{|c|}{$\begin{array}{c}\text { Economic capital (\%): } \\
\text { regBionally } \\
\text { Boncentrated portfolio } \\
\text { BBB }\end{array}$} \\
\hline $\mathbf{8 0} / \mathbf{6 2 0}$ & 4.83 & 1.13 & 1.13 & 1.23 & 1.95 & 2.17 \\
\hline $\mathbf{8 0} / \mathbf{6 6 0}$ & 3.25 & 0.76 & 0.77 & 0.84 & 1.31 & 1.54 \\
\hline $\mathbf{8 0} / \mathbf{7 0 0}$ & 2.14 & 0.50 & 0.51 & 0.56 & 0.90 & 1.00 \\
\hline $\mathbf{8 0} / \mathbf{7 4 0}$ & 1.39 & 0.33 & 0.34 & 0.38 & 0.59 & 0.70 \\
\hline $\mathbf{9 0} / \mathbf{6 2 0}$ & 8.71 & 2.38 & 2.38 & 2.65 & 4.20 & 4.68 \\
\hline $\mathbf{9 0} / \mathbf{6 6 0}$ & 6.46 & 1.76 & 1.83 & 2.02 & 3.19 & 3.70 \\
\hline $\mathbf{9 0} / \mathbf{7 0 0}$ & 4.40 & 1.20 & 1.27 & 1.42 & 2.20 & 2.44 \\
\hline $\mathbf{9 0} / \mathbf{7 4 0}$ & 2.94 & 0.80 & 0.83 & 0.92 & 1.46 & 1.70 \\
\hline $\mathbf{9 5} / \mathbf{6 2 0}$ & 11.85 & 3.41 & 3.50 & 3.89 & 5.85 & 6.58 \\
\hline $\mathbf{9 5} / \mathbf{6 6 0}$ & 8.96 & 2.56 & 2.70 & 3.08 & 4.55 & 5.18 \\
\hline $\mathbf{9 5} / \mathbf{7 0 0}$ & 6.19 & 1.76 & 1.99 & 2.17 & 3.13 & 3.58 \\
\hline $\mathbf{9 5} / \mathbf{7 4 0}$ & 4.15 & 1.18 & 1.30 & 1.46 & 2.23 & 2.49 \\
\hline
\end{tabular}

*Assumes diversified portfolio. 


\section{Table 12: Economic Capital for Seasoned (3-Year Old) Loans-Extended Model}

Simulated expected loss rates, foreclosure rates and capital charges by LTV and credit score, under BBB and A- solvency standards ${ }^{l}$

\begin{tabular}{|c|c|c|c|c|c|c|}
\hline \multirow{2}{*}{\begin{tabular}{|c} 
LTV $(\%) /$ \\
FICO- \\
Score \\
\end{tabular}} & \multirow[t]{2}{*}{$\begin{array}{c}\text { 8-year expected } \\
\text { foreclosure rate } \\
(\%) *\end{array}$} & \multirow{2}{*}{$\begin{array}{l}\text { 8-year expected } \\
\text { discounted } \\
\text { cumulative loss } \\
\text { rate }(\%)^{*}\end{array}$} & \multicolumn{2}{|c|}{$\begin{array}{c}\text { Economic capital (\%): } \\
\text { regionally diversified } \\
\text { portfolio }\end{array}$} & \multicolumn{2}{|c|}{$\begin{array}{c}\text { Economic capital (\%): } \\
\text { regionally } \\
\text { concentrated portfolio }\end{array}$} \\
\hline & & & $B B B$ & $A$ - & BBB & $A-$ \\
\hline $80 / 620$ & 6.35 & 1.66 & 1.44 & 1.56 & 2.32 & 2.62 \\
\hline $80 / 660$ & 4.28 & 1.12 & 0.98 & 1.07 & 1.55 & 1.82 \\
\hline $80 / 700$ & 2.83 & 0.74 & 0.67 & 0.73 & 1.03 & 1.22 \\
\hline $80 / 740$ & 1.85 & 0.49 & 0.44 & 0.49 & 0.69 & 0.83 \\
\hline $90 / 620$ & 11.28 & 3.43 & 2.98 & 3.30 & 4.85 & 5.46 \\
\hline $90 / 660$ & 8.39 & 2.54 & 2.33 & 2.56 & 3.70 & 4.27 \\
\hline $90 / 700$ & 5.73 & 1.74 & 1.62 & 1.81 & 2.53 & 2.89 \\
\hline $90 / 740$ & 3.84 & 1.17 & 1.07 & 1.19 & 1.67 & 2.00 \\
\hline $95 / 620$ & 15.22 & 4.88 & 4.35 & 4.73 & 6.83 & 7.51 \\
\hline $95 / 660$ & 11.55 & 3.68 & 3.43 & 3.79 & 5.28 & 6.11 \\
\hline $95 / 700$ & 8.00 & 2.54 & 2.50 & 2.77 & 3.66 & 4.16 \\
\hline $95 / 740$ & 5.38 & 1.71 & 1.62 & 1.85 & 2.56 & 2.94 \\
\hline
\end{tabular}

*Assumes diversified portfolio.

${ }^{1}$ Calculations assume loans were subject to a "burnout" period of 12 months (when market rate was below note rate by at least 100 basis points.) 


\section{Figure 1: Expected Loss and Economic Capital}

New and seasoned loans, with and without prior burnout

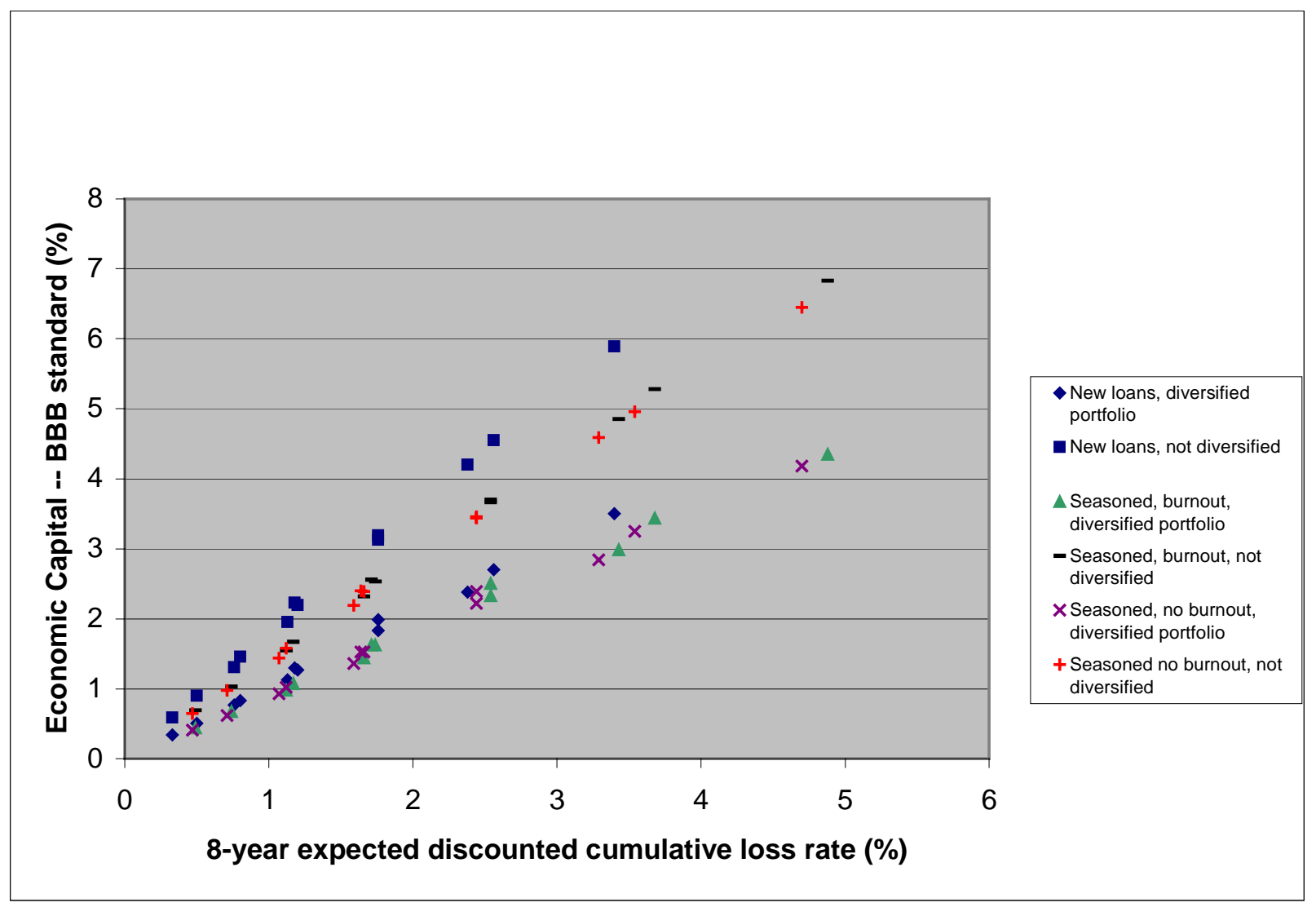




\section{Figure 2: Expected Loss and Economic Capital}

New loans, with and without private mortgage insurance

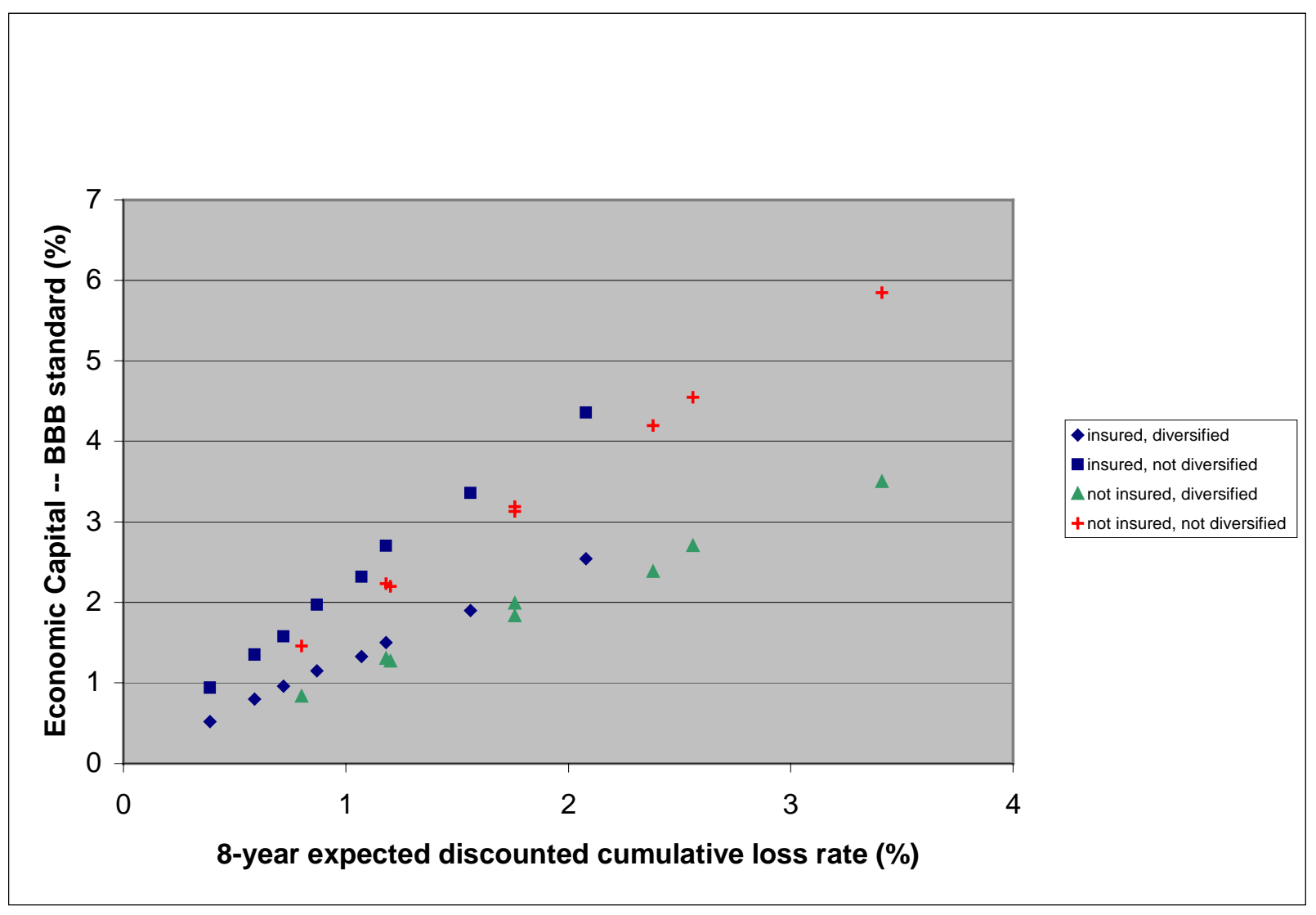


Figure A-1: Estimated Relationship between House Price Appreciation and Net Recovery

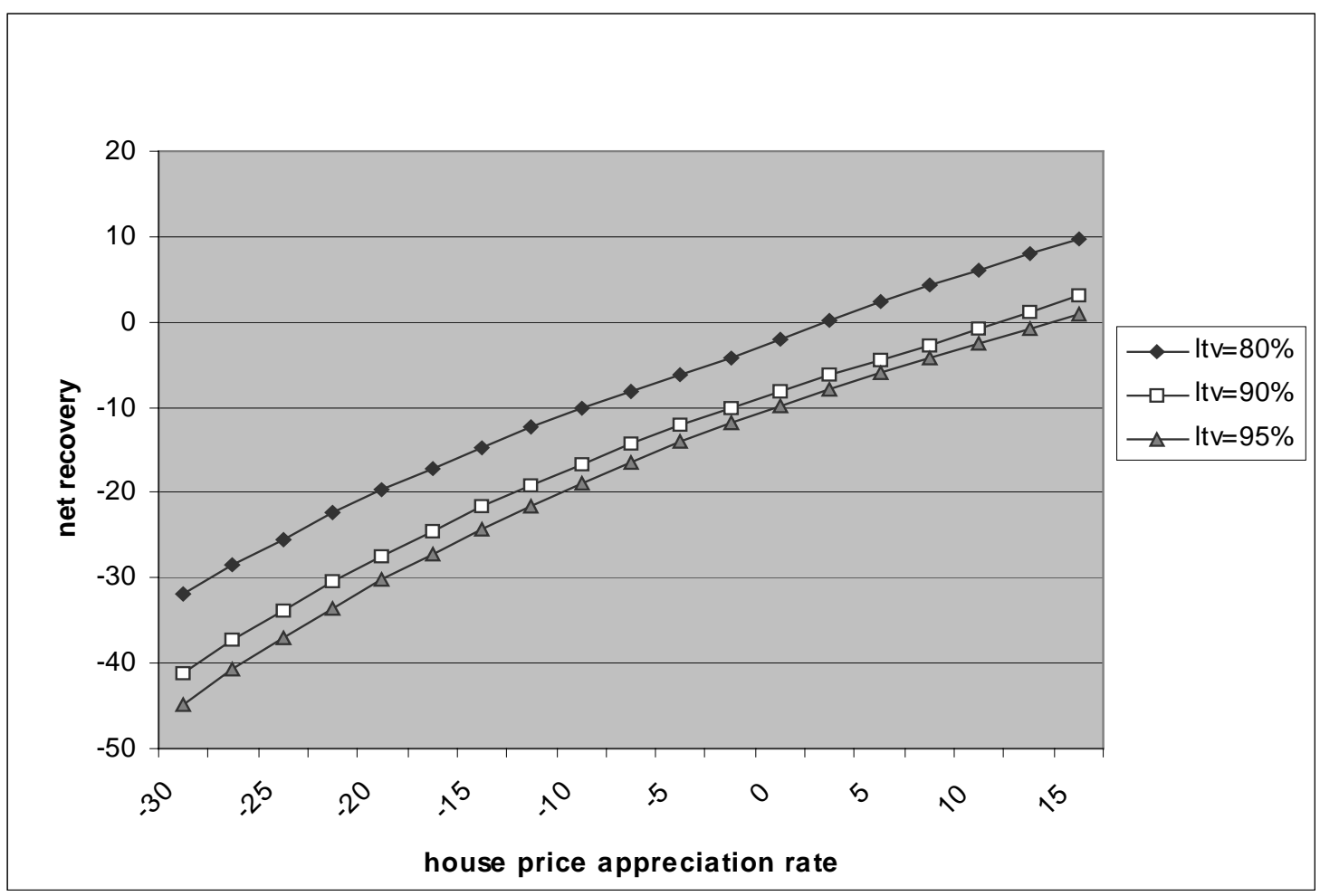

